Article

\title{
Food Systems Sustainability: An Examination of Different Viewpoints on Food System Change
}

\author{
Gareth Haysom 1,* E. Gunilla Almered Olsson ${ }^{2}$, Mirek Dymitrow ${ }^{3,4}$, Paul Opiyo ${ }^{5}$, \\ Nick Taylor Buck ${ }^{6} \oplus$, Michael Oloko ${ }^{5}$, Charlotte Spring ${ }^{6}$, Kristina Fermskog ${ }^{7}$, Karin Ingelhag ${ }^{8}$, \\ Shelley Kotze ${ }^{3,8}$ and Stephen Gaya Agong ${ }^{5}$ \\ 1 African Centre for Cities, EGS Building, University of Cape Town, Cape Town 7701, South Africa \\ 2 School of Global Studies, University of Gothenburg, Box 700, SE 40530 Gothenburg, Sweden; \\ gunilla.olsson@globalstudies.gu.se \\ 3 Mistra Urban Futures, Chalmers University of Technology, Läraregatan 3, 41296 Gothenburg, Sweden; \\ mirek.dymitrow@chalmers.se (M.D.); shelley.kotze@businessregion.se (S.K.) \\ 4 Unit for Human Geography, Department of Economy and Society, School of Business, Economics and Law, \\ University of Gothenburg, P.O. Box 625, 40530 Gothenburg, Sweden \\ 5 Jaramogi Oginga Odinga University of Science and Technology, Kisumu 40100, Kisumu County, Kenya; \\ popiyo2002@gmail.com (P.O.); moloko@jooust.ke (M.O.); sgagong@jooust.ac.ke (S.G.A.) \\ 6 The Urban Institute, University of Sheffield, 219 Portobello Street, Sheffield S1 4DP, UK; \\ n.taylor-buck@sheffield.ac.uk (N.T.B.); c.spring@sheffield.ac.uk (C.S.) \\ 7 City of Gothenburg, Department of Environment, Box 7012, 40231 Gothenburg, Sweden; \\ kristina.fermskog@miljo.goteborg.se \\ 8 Business Region Gothenburg, City Hall, SE-404 82 Gothenburg, Sweden; Karin.Ingelhag@businessregion.se \\ * Correspondence: Gareth.haysom@uct.ac.za
}

Received: 21 May 2019; Accepted: 12 June 2019; Published: 17 June 2019

check for updates

\begin{abstract}
Global food insecurity levels remain stubbornly high. One of the surest ways to grasp the scale and consequence of global inequality is through a food systems lens. In a predominantly urban world, urban food systems present a useful lens to engage a wide variety of urban (and global) challenges—so called 'wicked problems.' This paper describes a collaborative research project between four urban food system research units, two European and two African. The project purpose was to seek out solutions to what lay between, across and within the different approaches applied in the understanding of each city's food system challenges. Contextual differences and immediate (perceived) needs resulted in very different views on the nature of the challenge and the solutions required. Value positions of individuals and their disciplinary "enclaves" presented further boundaries. The paper argues that finding consensus provides false solutions. Rather the identification of novel approaches to such wicked problems is contingent of these differences being brought to the fore, being part of the conversation, as devices through which common positions can be discovered, where spaces are created for the realisation of new perspectives, but also, where difference is celebrated as opposed to censored.
\end{abstract}

Keywords: urban food system; food systems change; wicked problems; sustainability; urban food security

\section{Introduction}

There are such streams of energy running through this city and we have not yet sufficiently explored them. Hunger might help us to learn how to do that, it offers a possibility. Hunger is a good starting point for the incessant search for a beyond, for it reveals the paradox in which we are living: a country so rich, with water, rivers, sun, forests, and yet with inhabitants so miserable. There is a hiatus 
somewhere, a void, and this void needs to be filled. It is to be filled by us, the inhabitants of the city, the initiated, the shege, (street children) the expatriates, the multitudes of people that make up this city. (Vincent Lombume Kalimasse, Kinshasa, February 2004)

The introductory quote by a resident of Kinshasa may read as a strange entry point to an urban food system (UFS) article focusing on a collection of city food system engagements. However, it details a hunger, used in this paper metaphorically, to expose the sense of dissatisfaction that speaks across contexts. While the hunger in Kinshasa, as with Cape Town or Kisumu, may be real physical hunger and the need to access food, the hunger in Gothenburg or Greater Manchester may be a real hunger, but also a hunger for a more socially and ecologically just food system. This quote demonstrates three useful points; firstly, how food and the urban system connect [1,2], secondly, the utility of food as a means to speak to wider urban challenges and conditions, a lens [2] to investigate the city. Finally, it points to perspective and context [3] and everyday struggles across all cities.

Food, the food system and cities have always been connected, from the adoption of place-based agriculture [4], through the different processes of the industrial and agricultural revolutions [5-7], to revised place-based design concepts such as the Garden City Movement of Ebenezer Howard (see [8]). As Carolyn Steel [2] points out in her book Hungry City, until quite recently food directly impacted on the location, economic functions, the design, and how city and national politics play out. However, more recently, the relationships between cities and food have become increasingly disconnected. As food has increasingly become an instrument of trade, traded not as a public good [9] but as a commodity [10], the focus on food has shifted from a mandate, even if indirect, of city government, to a function of a liberalised market. This relationship, between urban food, city officials and planners and the state, is becoming increasingly vague.

However, more recently, as if to answer the writer Kalimasse's epigraph (cited in [11] (p. 261)), some cities have begun re-claiming their place as actors in urban food systems [12-15]. There are different and at times divergent reasons for this renewed urban food focus, but two particular motivators are argued to be central to this. First, is the scale of urban food insecurity (in broad terms-see [16,17]) and the broader developmental consequences that result from significantly high levels of food poverty. Secondly, current urban food systems are complicit in the overwhelming global inequalities in resource access and to the emergent outcomes from an unsustainable global food system, driven by various activities, but including both climate-hostile transportation modes and ecosystem-hostile agricultural methodologies. The current food system thus has a direct impact on the ecosystem which feeds back undermining the longer-term sustainability of the food system [18,19] and urban sustainability.

This article emerged from a novel UFS research engagement between food systems researchers from very different cities; Gothenburg, Sweden (GOLIP), Sheffield/Greater Manchester, UK (SMLIP), Kisumu, Kenya (KLIP) and Cape Town, South Africa (CTLIP). Each city and/or city-region faces different urban development challenges, and different and divergent food system challenges. This project sought to engage, in a collaborative manner, urban food system-related questions, specifically questions of food security and value chains, across these cities. From the outset, the project expected difference and contextual nuance, but it was expected that broader food-system thinking and approaches would align.

Documented here are the discursive processes where different researchers engage food system issues from their own context. Different political-economic contexts influence the focus of these researchers, driven by their city-respective challenges. However, while certain global food system trends and governance approaches hold relevance to broader UFS debates, context is important, but context is not the only informant of position. This view of the interplay between context and position is different from the challenge to the importance of context as a specific informant of a particular point in time, in stasis, and "a warning against reducing events and actors to a given context" [20] (p. 379). Context in the perspective of this discussion remains an important informant but is further complicated by factors other than temporal shifts.

The aim of the paper is to use the collaborative process to demonstrate that while theorisation in global food systems change is evolving rapidly, the evolution of concepts is informed by diverse 
and contextual political-economic realities, but also values held by researchers which influence how the issues are framed. This influences how collaborative projects emerge, evolve and frame particular issues.

For academics, areas of disciplinary focus may result in a specific world view on such issues, what could be described as one's level of reality [21]. Disciplinary focus is often informed by deep seated but personal value positions, values that attracted a researcher to a specific field in the first place. These value positions are also informed by personal choices playing out in the interplay between norms and values [22]. This raises interesting, and even challenging, academic questions: How do context, values, disciplinary orientation, institutional priorities, politics and culture intersect when researching UFS issues? What does this mean when engaging in transdisciplinary research from different contexts? What does this mean when engaging in projects aiming to better understand global sustainability questions?

From a transdisciplinary research perspective, understanding value positions, different "targets" and assessments of need is an essential first step. This article charts a process whereby different research units, with different food system positions, and different political economies, sought out areas of mutual concern for later research engagement and theorisation. Importantly while not the initial intention, what emerged was an appreciation for difference, both in terms of need and value positions. Reported herein are insights from an unresolved and evolving process, one that remains a work in progress.

The article begins with a brief discussion on the state of the urban food system. This is followed by a contextualisation of the different city food system engagements. We then discuss particular ideological differentiations evident in the food system framing (see [23]). These ideological positions were constructed to unmask the researchers' and their wider contextual political-economy informed positionality, scale and politics [24]. The different city positions are then mapped in terms of a generalised food system position perspective which is further supported by particular food system framings. The work concludes making an argument for far greater attention to process, for plurality and for the need to embrace positionality for the utility that it provides in navigating a way forward.

\section{A Note on Methods and Approaches Applied}

The methodological approach applied in this paper is that of co-production. This builds on earlier work on the subject by Polk and Kain [25] and Polk [26] where co-production "emphasizes the joint responsibility of involved actors as relevant sources of situated and scientific knowledge, in situ, context-based, problem solving" [26] (p. 111). Polk's work engaged wider sustainable development questions and situated co-production as a counter to the oversimplification of the interactions within and between science and policy [25] (p. 8). Polk's work argues that co-production is essential to enable equitable knowledge generating interactions between science, society and policy.

This article deepens this view but works from the premise that there are contested politics, values and power dynamics within science and even within a specific scientific discipline, engaging varied approaches and interpretations [27], in this case, urban food studies. We argue that the principles of co-production, including equitable and diverse knowledge positions and generation, collaboration (and not consensus), and situatedness-the multiple "objective" or "scientific" views of reality [25] (p. 8) have relevance to interactions between academics from different contexts.

Our process involved a series of meetings, held in the different partner cities. Initially city-specific urban food projects and perspectives were presented, followed by a process that sought to find alignment and overlap-consensus. Consensus was elusive. Different partners could not agree and as processes evolved, the ability to engage diminished as positions were defended.

The partners were all engaging in co-production processes between knowledge, society and policy in their active city-level projects (see Section 3). Co-production was thus seen to hold potential for collaborative project across all cities. As a result, at subsequent meetings, the co-production approach was revisited, but here co-production was applied across academic partners and not between 
knowledge, society and policy. In this process different value positions and food system framing perspectives were presented, discussed, and critically engaged.

At the final batch of meetings, partners articulated their positions, both to partners and in presentations to a public audience. Throughout the process the partners participated in collaborative research projects across the cities, deepening the understanding of specific city positions, values and needs. This understanding enabled critical reflection on the value positions of each city. The primary object of this work was to understand how different cities engaged urban food system sustainability, equity and food access, and how these different cities could collaborate in urban food system issues. A secondary question was whether lessons could be transferred across cities.

\section{The State of the City Food System and Responses}

As the preamble to a recent book on the role of civil society and social movements in urban food governance states "as global food systems face multiple threats and challenges there is an opportunity for [urban] social movements and civil society to play a more active role in building social justice and ecological sustainability" [15] (p. i). (In this case, academics are seen as civil society actors as they represent society but sit outside the state) In a predominantly urban world, cities are argued to be entry points to challenge wider food system related issues and concerns. The state of the current food system has been discussed in detail by others, covering ecological consequences [28], stubborn food insecurity [16], the increasing dominance of "big food" [29,30] and wider governance failures [31,32]. While dated, Donald's et al. 2010 [33] categorisation of food system debates reflecting the divergent perspectives on food system needs, remains relevant. This framing suggests that there are two dominant debates taking place about addressing the challenges within the food system. The first is the "consensus-based economic and ecological approach" or status quo-oriented stance, and the second the "inequality-based approach" which arises from a critique of the industrial food system [33] (pp. 172-173). The inequality-based approach seeks to privilege family farms, smallholders and community-based food systems [34] and represents a liberal-democratic orientation [33] adopting a political economy perspective challenging the current system and the role played by the state in maintaining vested interests within this system. These views form part of divergent perspectives seeking to understand wider food system failures and the ensuing solutions. However, many of these views often reflect a distinct rural bias, privileging production-oriented positions (availability) over a more inclusive view of food security incorporating all four dimensions of food security, rather than just the availability dimension $[35,36]$. While a more inclusive view was held by all cities in this research process most could be argued to fall within the inequality-based approach, what this meant was the presentation of divergent views of UFS change.

The projects analysed in this paper were diverse. Some were conceptual, others informed by empirical research led processes. In some cities, academics played a more activist role than in others, establishing structures that could engage in, or even disrupt, existing practices. A further model was a collaborative approach, where researchers and city officials worked to co-produce possible solutions. Detailed here is a summary of the different city projects. Projects were at different stages of implementation or research. The briefs below provide a city-generated summary to provide sense of the audience, theoretical approach and relationship with city governments.

\subsection{Gothenburg, Sweden}

Two different approaches form part of the Gothenburg process. One approach considers a more theoretical position on the state of the UFS by linking changes in the local food system to sustainability transitions in society [37-39]. The theoretical work was informed by a critique of the wider global food system. This project embodied several key focus or action areas: Required is a shift from dependence on the global food system towards reliance on local and regional food systems. A further shift, from conventional intensive agricultural methods to agroecological methods, promoting water conservation, nutrient recirculation, and biodiversity at all levels is required. Divergent knowledge sources are 
recognised as being essential to this process, leveraging the skills of many knowledge actors. Central to such a shift is a change in governance, from top-down expert dominated knowledge to bottom-up decision-making with the active involvement of local farmers and communities in specific geographic areas (local agency). At the core of this project is the initial theoretical development of as a food shed approach, one that sought the re-establishment of urban-rural linkages via local-regional food production $[37,38]$.

The second approach was one that was project-focused and is part of the Gothenburg Applied Food Strategy (GAFS), and engaged the day-to-day challenges encountered [40]. GAFS was developed within the EU-funded project Urban Rural Gothenburg. Urban Rural Gothenburg' targets primarily small- and medium-sized enterprises by making use of the local communities in the socio-economically challenged north-eastern Gothenburg and its human resources to transition into a more sustainable society. The targeted businesses are chiefly to be related to the food value chain "from farm to table", which involves not only food producers, conveyors and logisticians, but also distributors, marketing, communications and IT specialists, stores and local markets, restaurants, hotels and other tourism-related businesses, as well as recycling and knowledge enterprises. GAFS aims to drive greater food system change through targeted procurement for the school feeding program [41]. Here the central focus is on seeding change in the wider city food system enabled by leveraging city resources to enable sustainable and environmentally sound school meals [42]. These approaches included environmentally labelled foods, seasonally appropriate ingredients, meals that contained a large share of plant-based proteins, vegetables and legumes [43]. If fish products were used, these were sustainably harvested and were not endangered. Fair and equitable considerations are applied to procurement decisions relating to sourcing, pricing and staffing and form as an important component to the program. Food waste needs to be directly reduced and product sourcing needs to ensure that food waste is not an externalized factor in the products procured. The overarching objective of these integrated programs is to increase knowledge in the school environment about environmental and sustainability issues and the food's environmental impact [44]. These programs reflecting sustainability and ethical values have shown to be somewhat more challenging to implement, largely due to the scholars' desire for "Western fast food-type" foods and due in no way to limitations associated with the sustainability or ethical components of this program. These remain an ongoing process of iteration and a constant pushback against the outcomes of the dominant globalized food system [45].

\subsection{Sheffield/Greater Manchester, UK}

Greater Manchester and Sheffield share certain commonalities (histories of rural dispossession, cooperative movements, industrial decline and transitions to city-regional governmental structures). Both city-regions have produced localised strategies with relevance to the food system. Problems identified include poor diets associated with low income and geographical distance from affordable food outlets, environmental impacts of long-distance, intensive food chains, high levels of wastage [46] and the dominance of transnational corporations over food flows, prices and processing. Opportunities have been glimpsed for food system change to achieve economic, health and environmental urban policy targets. However, there is a recognised lack of coordination between different sectors' and departments' efforts, and declining local government funding to enact strategies. Under-resourced city councils have re-positioned themselves as "enablers" of coordinated action by business and civil society to achieve food system change, drawing on governance models such as food policy councils or the 'Sustainable Food Cities' movement [47,48].

It is in this context that the Self-organising Action for Food Equity (SAFE) project aims to assist the development of city-region food strategies. The project uses principles of participatory action research and coproduction to better understand how to organise, harmonise and capitalise on the energy, knowledge and expertise of different sectors and projects. Action Research Teams (ARTs) were convened, including cross-sectoral food system actors: local government (especially public health) officials, academia, civil society organisations, food industry actors and consultants It is worth noting 
that while this was the target audience and reflected the composition of the project at inception, different parties were more invested in the ongoing process than others. The process seeks to combine diverse knowledge, supporting different layers of formal and informal food governance to assist, develop and support local initiatives to share learning, skills and resources. The researchers proposed that achieving whole-system change requires people and communities to cohere around key issues without necessarily signing up to any overarching grand vision.

One strand of the project has been to evaluate and share insights on how expertise and information in urban food systems is collected, presented and shared by co-designing a communications hub or 'digital infrastructure'. Participants were facilitated in developing an open-source, open-access online platform that users can modify and adapt so that it can evolve and gain longevity. However, issues of ownership, maintenance and control frequently arise in a project involving diverse stakeholders with varied needs, priorities and resources.

\subsection{Kisumu, Kenya}

Located on the banks of Lake Victoria in Kenya, Kisumu has encountered many food-system shifts, from the depletion of a key protein resource in the Lake, as a result of the introduction of the Nile Perch [49], to more recent ecological challenges driven by increased effluent and agricultural run-off into the lake and the increase in water hyacinth [50]. The land-based resource has also seen significant change where traditional and more localised crops have been replaced with cash crops such as sugar. However, discussions on the agricultural and resource access strategies often mask the original founding reasons of the city. Kisumu started as a trading centre where foods from the region were traded and distributed more widely. For many in Kisumu, access to food through the market remains the primary source of food.

Kisumu engaged in a number of diverse food system projects. Two key projects were focused on in this project, one was an enquiry into the local food markets [51] and second, a wider food systems research project, the Consuming Urban Poverty (CUP) Project $[1,52,53]$. Both the markets project and the CUP project sought to bring together diverse research and implementor teams that spanned disciplines. External researchers were also welcomed, with the motivating position being that external researchers identified issues that are often normalised in a local context.

Both the CUP project and the markets project carried an overarching position of the essential need for food sensitive design and planning. This may appear obvious, but for many cities like Kisumu, food is the mandate of national or regional governments with local or city governments having little food system authority. Adopting a planning approach to the UFS reclaims the food mandate at the local scale and reclaims governance responsibilities for food security dimensions of food access, utilisation and stability [54]. A key finding from the Kisumu research is that the formal and informal food systems are in fact one system-and operate as one [55]. More importantly, both components of this wider food system are used strategically by consumers in the struggle to access affordable nutritious foods. It is the informal economy that is proactively enabling access to affordable essential foods. Here an interesting value conundrum emerges where traders were importing fish (an essential protein source) from China, while selling local fish for a higher price in Nairobi. There exists a clear tension between enabling access to essential proteins and somewhat privileged views of local food systems.

The Kisumu food team co-produce policy interventions targeted at key food system decision makers through an engagement with a diverse stakeholder group that includes government officials, market operators, civil society and academics.

\subsection{Cape Town, South Africa}

The Cape Town food system work builds on 10 years of food system engagement in research and engagement with city officials. This historical relationship resulted in the commissioning and drafting of a citywide food strategy for the City of Cape Town in 2014 [56]. The processes associated with this strategy are instructive as they reflect the tensions between politics, scarce resources, a liberalised 
perspective of the food system - a view that the private sector can deliver more efficiently-and the City's rejection of any process that would stimulate local or bottom-up agency. The result was that Cape Town is perhaps the first African city with a detailed and robust food strategy, but this strategy was until recently (late 2018) side-lined by the city. Recent changes in city leadership have resulted in the emergence of a renewed interest in wider UFS processes.

Other factors have also worked to elevate the profile of the Cape Town food system work. One has been the active engagement in processes associated with the retention of the Philippi Horticultural Area (PHA). The PHA is a 3000-ha area of land zone for horticulture (of which about 2000 ha is farmed) surrounded by urban activities. Here farmers of all scales produce food for sale in the city and beyond [57]. The land has for the past 10 years been the subject of many development applications seeking to change the land use to enable middle- and upper income housing [58].

High levels of food insecurity were identified in earlier (2008) research [59]. Recent research, representative of the entire city shows that this has not changed [60]. Food access for poor residents is via a variety of sources with large monthly purchases being made through supermarkets, and the informal sector remaining a key food access point, often enabling food access through strategies that respond to the needs of the poor (such as bulk breaking or short-term credit) [60].

Context is an essential consideration and is particularly important in cities where needs, history, and even governance structures all intersect with food system processes [61,62]. In attempting to understand the different views held by the different urban researchers in this project, researchers drew on the framing of food system positions developed by Holt Giménez and Shattuck [23]. However, while relevant theoretically, when engaging city-level food system challenges it was found that these positions required further expansion. The positions were expanded to include food system areas of focus and scales of action. Added to this was an assessment of food system 'values'. Through this process, four intersecting food system response typologies were formulated as a tool to accentuate the binaries between different food system positionalities.

\section{Food System Positionalities}

Different food system value positions inform how researchers, activists and even policy makers engage remedial actions pertaining to the food system. As part of the collaboration process in this project these binaries or food system positionalities were constructed as a tool or methodological instrument to expose positions which are often assumed to be universal. These are deliberate frames or categorisations intended to make specific positions clear. For the purpose of the article they are simply tools that clarify positions (and values). In other contexts, project, situations other boundary framings can be used.

Although presented here as binaries, such positions are never fully exclusive and there is always overlap between such positions. This may be informed by value positions that are less rigid, contextual needs and even differing positions within each area of focus. The areas of overlap offer clues as to where opportunities for collaboration and innovation lay.

The resource focus challenges the dominance of the so-called industrial food system [28], holding a broader sustainability ethic. The agricultural resource focus emulates Birkeland's $[63,64]$ notion of positive development-many within this field argue that food production can be restorative rather than simply remedial [65-67]. A more unifying approach within this group is embodied within the agroecology movement $[38,68,69]$. This group is also made up of a number of different production approaches, often falling within the ambit of agroecology, but with specific foci [28,70-72]. The "culture of care" [33] is on the soil [73], water [74] and biodiversity [66], holding a distinct resource view. Social wellbeing, rights and equity are contained within their broad approach, but their focus is on the ethics of care and not necessarily rights.

The green focus spans the food system but hold a distinct consumer focus. The emphasis is food system structures. The value-driven approach focuses on restructuring the system, aligned with green aspirations [75], generally driven from the consumer end of the food value chain [76] with the key 
domains of action being supermarket chains (See: http://www.woolworthsholdings.co.za/investor/gbj/ 2010/environment/f.asp and http://www.woolworths.co.za/store/fragments/corporate/corporate-index. jsp?content=corporate-landing\&contentId=fol110077; https://www.about.sainsburys.co.uk/makinga-difference/our-values/our-stories/2017/energised-colleagues-save-2-million-in-carbon). The political project of this group is that of assurance where consumers are protected or 'assured' by being advised what is sustainable. This is generally a store or brand label-driven process that often make the responsible act the duty of the consumer. The green approach generally accepts the existing overall system but seeks to initiate changes from within this system.

Those holding a food justice perspective also hold a food system view. One of the key projects within this group includes the food sovereignty movement (predominantly production-focused) [77], and other predominantly consumer-focused groupings and issue areas such as food safety, food health and food quality A strong political line associated with justice and cultural recognition is evident. The group actively favours small and family farmers (See www.caff.org) and is distinctly anti-globalisation. This group also contains those focusing on the rights of other "actors" within the food system, including animal rights and welfare [78,79].

The scale-focused group is diverse. This group's key political project is one of community (broadly defined) with a distinct focus on place, or scale, and the space of flows [80]. One of the key organising principles within this grouping is that of embeddedness [81] or the "re-placement of food within its social, cultural, economic, geographical and environmental contexts" [82] (p. 2). The political practice of re-embedding is thus a core focus [83]. Focus is on areas such as food miles [84], ecological footprinting $[85,86]$ and food production at the urban scale [33]. This group is most active is in local food governance [15,87-91], including food democracy, engagement in food policy structures, and local and regional food governance interventions. The connection between governance, flows and embeddedness enables new and novel ways of imagining how food systems are governed.

Values and the embedded politics in how food system change should be approached at the urban scale is further informed by a wider understanding of the food system itself.

\subsection{Food System Framings and Representations}

While many different framings of the food system exist, specifically as it relates to food security and development challenges exist, four food system representations were considered in this project, detailing the positioning of the food system within wider systemic processes. The nature of the systemic processes often impacts on how the food system itself is framed.

The three sustainability oriented framings (in very broad terms) considered included Ericksen's (2008) [92] framing of a food system and its impact on and consequences of global environmental change; Blay-Palmer et al. (2018) [93] and their depiction of the food system through the lens of the Sustainable Development Goals (SDGs) and; Schipanski et al. (2016) [94] who consider resilience and the different food system interventions that would either enable or constrain resilience. The fourth framing was governance oriented and considered the scales, or levels, of policy intervention in the food system [95]. Ericksen's [92] food system framing "includes the major activities and actors involved in food systems, as well as the critical processes and factors influencing the social and environmental outcomes that are also part of a food system" [92] (p. 238). Central to Ericksen's depiction is that food system outcomes include food security, environmental security and other societal interests [92] (p. 239). Adopting a very different approach, Blay-Palmer et al. (2018) [93] seek to engage the food system through the lens of the SDGs. This view is divergent in its offering of "a critical assessment of the value and utility of the evolving CRFS approach to improve insights into flows of resources-food, waste, people, and knowledge - from rural to peri-urban to urban and back again, and the policies and process needed to enable sustainability" [93] (p. 2). Schipanski et al. (2016) [94] consider the integration of multiple strategies, or "wedges," operating at "the local or regional context" [94] (p. 608). These wedges shift the food system resilience away from the business as usual approach. 
When considering governance, Ecker and Breisinger demonstrate the intersections between the "macro and micro views" [95] (p. 4) of the food and nutrition system. This perspective positions the macro aspects at the scale of the economy and the state and the micro activities at the scale of the household and its members. For this project, framing different value positions, politics, needs and even food systems understandings was deemed an essential part of engaging a wider inter-disciplinary project on urban food system change as the practice and engagement in alternative food governance and food system processes is not a process in which consensus and agreement exist.

Perhaps most problematic with all food system framings is that most re-enforce conventional food system framings where the macro scale considers trade, economy and production. Views then descale to the household scale (micro scale) referencing either the household or individual as the area of analysis or action—a view which is informed by Sen's (1981) entitlements perspective [96]. Absent is any proactive focus on the meso, or mid-scale, particularly the urban scale $[15,97]$. From an urban food systems policy and change perspective, these framings reinforce existing dogmas and policy positions and are, in the main, counterproductive. While flows of food enter the city from wider scales, if the city is seen as an essential driver of food system processes, and as such unsustainability, governance and food system actions at the scale of the city are an essential area of intervention.

\subsection{Combined Responses and Processes to Enact Food System Change}

The next section reflects on the city processes and details some of their core architecture. These processes have two things in common. Evident in their "theory of change" is either a specific concern for place where change related processes operate from that specific context. The other entry point is a deeply held view, informed by a critique of the current food system, and an imagination of what the ideal system should encompass. Here the ideological positions detailed earlier are an important factor. All positions have relevance but are mediated through the needs of a particular context and the wider food system. If all actors in the process held the same ideological position, a more values driven position could have been adopted in our co-production process. However divergent value positions were present, different knowledge systems were evident, and the contextual needs and challenges in the different cities were very different.

When viewed as a collective project, the different positions and areas of focus offer insights into different food system processes active in the different cities. While views may differ from one city actor to another, informed largely by their own values and other factors, a general representation depicts the different areas of focus and value orientations within the different city projects. For this purpose, framework analysis was employed as the principal method. Framework analysis is a tool to create an audit trail between the original material and the final conclusions [98]. It is used to organize and manage research by means of summarization, resulting in a robust yet flexible matrix output which allows for analyzing data both by case and theme. By borrowing principles from different epistemological traditions, framework analysis works independently of theoretical approach as long as sufficient preliminary thinking about the studied material has been done. The method is most effective for analysis of primary data, where it can be used to test a theory or to develop it [99-101].

The results of the undertaken analysis are shown in Figure 1. The positions were formulated by ranking the descriptions of the city projects against jointly constructed matrices of value positions, followed by detailed discussions on these positions. From this, four principal positions emerged for each city. These were then explicitly verbalised and accepted by each city partner, confirming that these ratings reflected their position. A numeric value was then assigned by way of city partners positioning their specific value positions on a scale of 1 to 10 , with 10 indicating complete adoption of a specific value position, in planning and practice. These were then discussed and agreed to be reflective of the city's position across the scale, justice, green and resource value position. 


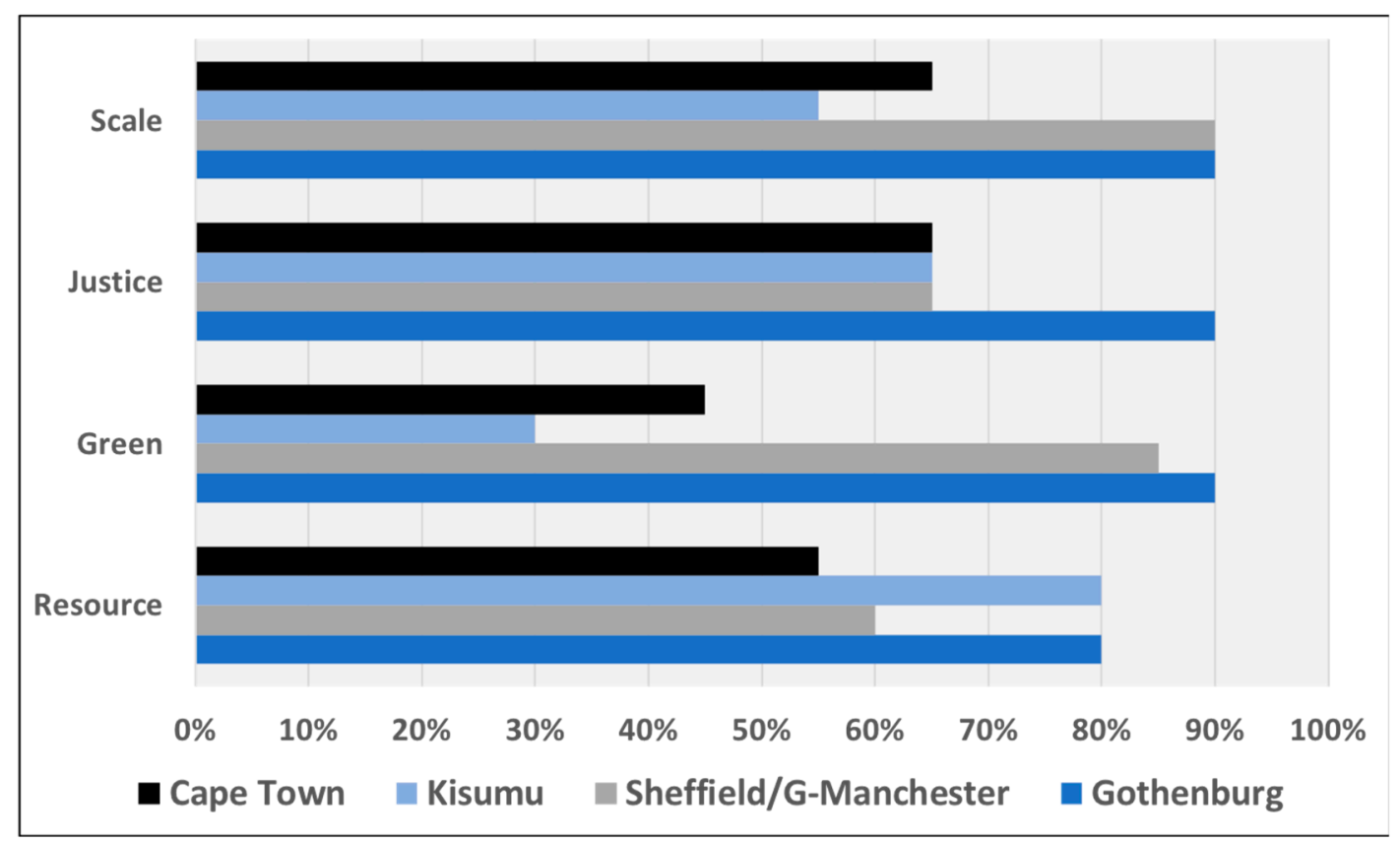

Figure 1. City-specific food system areas of focus.

All cities held a general view towards justice with Gothenburg being a slight outlier. The scale focus reflected an interesting trend, one that is evident in much Northern literature and one where the sense of agency and more pluralistic governance opportunities make the scalar focus an attractive area for interventions. This is not to suggest that for Kisumu and Cape Town place was not important but activating change through an agentic-driven approach is less likely to deliver change. The green agenda is far less important in Cape Town and Kisumu, informed largely by the essential need to enable to access food, given the high levels of food insecurity, where green is a luxury that does not apply when the daily struggle for many is simply putting food on the table. The resource focus presented a more mixed prioritisation where Kisumu retained a resource focused approach. Sheffield/Greater Manchester saw food production as part of a wider urban regeneration process, in this case through urban agriculture, viewed as a form of therapy, urban 'greening' or educational tool.

These assessments are subjective and are informed by very broad generalisations, used to depict the different areas of focus and views of food system change, rather than explicit policy positions.

More importantly, what this shows is where areas of convergence in terms of views sit, and where divergent positions may lie. Teasing these out through a collaborative process was perhaps somewhat more complex.

As a result of these variations, and in order to arrive at a transdisciplinary approach that saw the enactment of co-produced food system approaches across the partner cities, it was necessary to formulate a means with which to engage and enable the possible emergence of combined food system positions. Work carried out by Dorado et al. [102] (2009) and Rein and Stott (2009) [103] on Cross Sector Partnership (CSP) was considered. Here the focus was not one of seeing the different urban food positions as being different sectors, but rather understanding processes and how the differences in logics and framing might be brought into alignment in ways that allow productive and prosocial joint activities [104]. However, as Powell et al. (2018) [104] (p. 624) point out, "work on cross-sector collaborative activities ... has attended much less to the conflicting interests that may precede, contextualize and outlast attempts to work together to pursue prosocial efforts". Given the preceding assessment of positions, while holding merit, such CSP-type approaches were deemed inappropriate. A second facilitated engagement process convenes participants from very different value positions, positions of power and imaginations of outcomes, to seek out a common end solution. Examples of such facilitated food system processes include the Sustainable Food Lab (SFL) For Europe, 
North America and Latin America see: https://sustainablefoodlab.org from; for the Southern African Food Lab see: https://www.southernafricafoodlab.org. Both processes rely on carefully held and expertly curated engagement processes to mediate issues of power, different knowledges, contextual positions, ideologies and others. As a group of academics working on a combined food system engagement, resource constraints and distance between cities meant that such a facilitated process was not possible.

In this project, each city was engaging in their own contextual issues, each partner held very specific value positions on the importance and urgency associated with these issues. Seeking some sort of agreement was not the objective. As a result, the process included a collection of meetings held between partners, culminating in a process where the different perspectives and viewpoints were presented as a combined project, one that sought to recognise the differences and positionalities. Following from this was a process where collaborative and mutually agreed projects could then emerge. These projects reflected the areas where overlap in positions existed, but where contextual specificities were retained.

Where consensus was achieved was in the food system framing. Perhaps due to the adaptability of the food system frame, the work of Schipanski et al. (2016) [94] offered great utility. Each partner could easily identify their specific transformation wedges and what was required to move the contextual needs towards greater resilience.

\section{Discussion-Celebrating Difference}

When considered from a perspective of the focus, the scale and ideology of a particular alternative food system response, different perspectives became explicit. Initial processes in the collaboration process noted a distinct holding of positions, defending specific views and even, albeit indirectly, rejecting other positions. In one collaborative meeting the chair offered a useful and insightful interjection:

How do different city researchers reconcile major global challenges and is agreement necessary? Where there is considerable food poverty in one area is it appropriate to call for local and organic foods? However, where there are resources and a real will to engage the significant climatic challenges faced by society why could this not also be a vehemently held principled position? Both have relevance, and both are essential considerations. The objective, even responsibility, of a nested researcher, in a particular context is to prioritise according to the urgency of need in that specific city. [105]

Detailing difference is useful for three reasons: The first is to assist in identifying the key positions that different researchers hold. Secondly, it allows for recognition of certain non-negotiables, areas or issues that participants are not willing to surrender, or whose context drives such a need. Finally, and perhaps most importantly, when read as a collection of responses all focusing on the same objective- - that of food system transformation-it shows how all actors, despite holding different ideological positions, are in fact working towards a common goal, and not opposite goals. This recognition is useful because while highlighting ideological positions, it has the potential to start discussions about where the middle ground may lie, where opportunities for compromise lie. Working through the processes of building recognition for divergent views and differing options is not new.

Addressing the "wicked problems" [106,107] of a failing or flawed system have been the subject of a number of process facilitation engagements to seek to bring about food system change through dialogue and facilitated actions. Here a wicked problem is a challenge that "defies resolution because of the enormous interdependencies, uncertainties, circularities, and conflicting stakeholders implicated by any effort to develop a solution" [107] (p. 1160). However, at a local scale, researchers, policy makers, and food system change agents do not have the luxury of inaction as a result of the wicked nature of the issue, positions need to be taken and action often follows. Manufacturing agreement and collaboration that dilutes context specific actions is counterproductive. 
For transdisciplinary and trans-contextual research into food system challenges, consensus is argued to be a false hope, a form of co-option that dilutes deep and meaningful engagement. Finding ways to unearth and give life to difference and vastly different world views, particularly in the case of food system research where value positions are strongly held, and contradictory views often disregarded, is an essential part of inter- and trans-disciplinary collaborative work. This process was by no means perfect and many retain strongly held positions. However, the real value is that these positions are understood, accepted (if not necessarily embraced) and appreciated. Context remains the key informant and views seen as universal from one perspective or world view are now understood to be less relevant elsewhere-at least at the current time.

\section{Conclusions}

When critiquing the current food system, different politics and areas of focus in the food system are informed by a particular view of, and site of engagement in, the food system. There is no doubt that the global sustainability perspective remains the primary area of focus and an essential terrain for change within the wider project reported on here. However, as discussed, this global view generally missed (or even ignored) the urban scale. This is particularly evident in policy circles where the missing middle of the urban scale is a critical gap (a syllogistic fallacy known as the undistributed middle). Focus shifts from the global and/or national scale to the household scale, missing the urban scale. In the process the challenges and opportunities at the urban scale are over-looked. If the city is brought into the discussion, proposed solutions are often drawn from a generalisation of proposed global solutions or scaled up from the household. Neither are adequate.

For researchers working at the urban scale and engaging food system related issues different development needs intersect with different value positions and different assessments of urgency. This is evident within city projects but particularly evident in multi-country and multi-regional collaborative research projects. It is for this reason that the Northern cities were more interested in 'green' policies compared to the Southern locations where real calorific hunger is prevalent. These different rationalities (or rationalisations) clashed and could have been sites of conflict and enclavisation. Working through multiple viewpoints and constructions of reality, through direct engagement in food system values and focus, enabled a realisation of, and appreciation for, difference within a particular context. It was this appreciation for contextual needs, embedded within wider critiques of the food system that saw the emergence of collaborative processes where single solutions were discounted, but broader overarching principles agreed.

If different food system positions are known and foregrounded, two immediate benefits are apparent: Firstly, the ability to work in inter- and transdisciplinary ways are enhanced and enriched as personal non-negotiable positions are clear, avoiding lengthy negotiations. Secondly, this up-front clarification creates spaces in which tensions are celebrated and differences embraced, unmasking possible common but often unseen positions, but also possible areas of collaboration.

We argue that the identification of novel approaches to wicked problems is contingent on difference being brought to the fore, being part of the conversation. It is the identification of difference that become the levers through which common positions can be identified, where spaces are created for the realisation of new perspectives, possibilities and axioms. Importantly, this creates spaces where difference is celebrated as opposed to being censored or muted. Noting these positions up front, at the start of a collaborative (or co-production) process, assists greatly in avoiding lengthy and often conflictual processes where agreement is ultimately curated, representing a false consensus.

The engagements detailed in this paper represent processes that are similar to many sustainability engagements across context and across value positions. Many of sustainability's "wicked problems" are being engaged by academics who, due to the complex nature of the challenge, have to traverse the domains of knowledge, policy and society. As a result, using a co-production approach to a collection of academics held great utility. Being able to identify new areas for engagement, novel approaches 
and spaces for collaboration, where despite contextual differences co-learning could take place made visible the spaces and processes that supported further dialogue and equitable collaboration.

Author Contributions: Each author has made substantial contributions to the conception and design of the article. Each author reports on their specific city-level component of the wider project reported on in the article. The article was conceptualised at a meeting held in November 2018 at which all authors were present, and the design and structure of the article agreed. Each author has reviewed, approved and accepted the final submitted article. While each author was directly involved in the article, some led certain aspects of the paper: Conceptualization (All); Writing-Original Draft G.H., E.G.A.O., M.D.; Preparation, G.H.; Writing—Review \& Editing (All).

Funding: This article is based on work undertaken as part of the Mistra Urban Futures programme, which is mainly funded by Mistra-the Swedish Foundation for Strategic Environmental Research-and SIDA-the Swedish International Development Cooperation Agency, within the SKILLs co-operation.

Conflicts of Interest: The authors declare no conflict of interest.

\section{References}

1. Battersby, J.; Watson, V. (Eds.) Urban Food Systems Governance and Poverty in African Cities; Routledge: Oxon, UK, 2019; ISBN 9781138726758.

2. Steel, C. Hungry City—How Food Shapes Our Lives; Chatto and Windus: London, UK, 2008; ISBN 0701180374.

3. Haysom, G. Food and the city: Urban scale food system governance. In Urban Forum; Springer: New York, NY, USA, 2015; Volume 26, pp. 263-281.

4. Pacione, M. Urban Geography: A Global Perspective, 3rd ed.; Routledge: New York, NY, USA, 2009; ISBN 9780415462020.

5. Lewis, A. Economic Development with Limited Supplies of Labor. Manch. Sch. 1954, 22, 134-191. [CrossRef]

6. Lewis, A. The Theory of Economic Growth; Allen and Unwin: London, UK, 1955; ISBN 9780043300541.

7. Beall, J.; Fox, S. Cities and Development; Routledge: London, UK, 2009; ISBN 9780415390996.

8. Culpin, E.G. The Garden City Movement Up-to-Date; Routledge: Oxon, UK, 2015; ISBN 9780415748735.

9. May, J. Food Security and Nutrition: Impure, Complex and Wicked? Food Security SA Working Paper Series No.002; DST-NRF Centre of Excellence in Food Security: Cape Town, South Africa; University of the Western Cape: Cape Town, South Africa, 2017.

10. Friedmann, H.; McMichael, P. Agriculture and the State System: The rise and decline of national agricultures, 1870 to present. Sociol. Rural. 1989, 29, 93-117. [CrossRef]

11. De Boeck, P.; Pissart, M. Kinshasa: Tales of the Invisible City; Ludion: Brussels, Belgium, 2004.

12. Baker, L. Tending Cultural Landscapes and Food Citizenship in Toronto's Community Gardens. Geogr. Rev. 2004, 94, 305-325. [CrossRef]

13. Blay-Palmer, A. The Canadian Pioneer: The Genesis of Urban Food Policy in Toronto. Int. Plan. Stud. 2009, 14, 401-416. [CrossRef]

14. Carey, J. Who Feeds Bristol? Towards a Resilient Food Plan; A Baseline Study of the Food System That Serves Bristol and the Bristol City Region; Bristol City Council: Bristol, UK, 2011.

15. Andree, P.; Clark, J.K.; Levkoe, C.Z.; Lowitt, K. (Eds.) Civil Society and Social Movements in Food System Governance; Routledge: Oxon, UK, 2019; ISBN 9780429503597.

16. FAO; IFAD; UNICEF; WFP; WHO. The State of Food Security and Nutrition in the World 2018. In Building Climate Resilience for Food Security and Nutrition; FAO: Rome, Italy, 2018.

17. Crush, J.; Frayne, B. The Invisible Crisis: Urban Food Security in Southern Africa; Urban Food Security Series, No. 1; African Food Security Network (AFSUN); Unity Press: Cape Town, South Africa, 2010; ISBN 978-0-9869-8200-2.

18. Swilling, M.; Annecke, E. Just Transitions: Explorations of Sustainability in an Unfair World; Juta: Cape Town, South Africa, 2012; ISBN 978-92-808-1203-9.

19. Intergovernmental Panel on Climate Change (IPCC). Summary for Policymakers. In Global Warming of $1.5^{\circ} \mathrm{C}$; An IPCC Special Report on the Impacts of Global Warming of $1.5^{\circ} \mathrm{C}$ above Pre-Industrial Levels and Related Global Greenhouse Gas Emission Pathways, in the Context of Strengthening the Global Response to the Threat of Climate Change, Sustainable Development, and Efforts to Eradicate Poverty; World Meteorological Organization; IPCC: Geneva, Switzerland, 2018. 
20. Asdal, K. Contexts in action-And the future of the past in STS. Sci. Technol. Hum. Values 2012, 37, $332-354$. [CrossRef]

21. Nicolescu, B. Transdisciplinarity: The hidden third, between the subject and the object. Hum. Soc. Stud. 2012, 1, 13-28. [CrossRef]

22. Hansson, S.O. The Structure of Values and Norms; Cambridge University Press: Cambridge, UK, 2001; ISBN 9780511498466.

23. Holt Giménez, E.; Shattuck, A. Food crises, food regimes and food movements: Rumblings of reform or tides of transformation? J. Peasant Stud. 2011, 38, 109-144. [CrossRef] [PubMed]

24. Rose, G. Situating knowledges: Positionality, reflexivities, and other tactics. Prog. Hum. Geogr. 1997, 21, 305-320. [CrossRef]

25. Polk, M.; Kain, J.H. Co-producing knowledge for sustainable urban futures. In Co-Producing Knowledge for Sustainable Cities; Polk, M., Ed.; Routledge: Abingdon, UK, 2015; pp. 17-38. ISBN 9781138813618.

26. Polk, M. Transdisciplinary co-production: Designing and testing a transdisciplinary research framework for societal problem solving. Futures 2015, 65, 110-122. [CrossRef]

27. Longino, H.E. Science as Social Knowledge: Values and Objectivity in Scientific Inquiry; Princeton University Press: Princeton, NJ, USA, 1990; ISBN 9780691020518.

28. Frison, E.A.; IPES-Food. From Uniformity to Diversity: A Paradigm Shift from Industrial Agriculture to Diversified Agroecological Systems; IPES: Louvain-la-Neuve, Belgium, 2016; p. 96.

29. Monteiro, C.; Cannon, G. The Impact of Transnational "Big Food" Companies on the South: A View from Brazil. PLoS Med. 2012, 9, e1001252. [CrossRef] [PubMed]

30. Stuckler, D.; Nestle, M. Big Food, Food Systems, and Global Health. PLoS Med. 2012, 9, e1001242. [CrossRef] [PubMed]

31. Lang, T.; Barling, D. Food security and food sustainability: Reformulating the debate. Geogr. J. 2012, 178, 313-326. [CrossRef]

32. Termeer, C.J.; Drimie, S.; Ingram, J.; Pereira, L.; Whittingham, M.J. A diagnostic framework for food system governance arrangements: The case of South Africa. J. Life Sci. 2018, 84, 85-93. [CrossRef]

33. Donald, B.; Gertler, M.; Gray, M.; Lobao, L. Re-regionalizing the food system? Camb. J. Reg. Econ. Soc. 2010, 3, 171-175. [CrossRef]

34. Lyson, T. Civic Agriculture: Reconnecting Farm, Food and Community; State University Press: University Park, PA, USA, 2004; ISBN 1584654147.

35. Food and Agriculture Organisation (FAO). World Food Summit; Rome Declaration on World Food Security: Rome, Italy, 1996; Available online: http://www.fao.org/WFS/ (accessed on 19 January 2014).

36. Dymitrow, M. Rural/Urban Redux: Conceptual Problems and Material Effects; Department of Economy and Society, University of Gothenburg: Gothenburg, Sweeden, 2017; ISBN 978-91-629-0360-2.

37. Olsson, E.G.A. Urban food systems as vehicles for sustainability transitions. Bull. Geogr. Soc. Econ. 2018, 40, 133-144. [CrossRef]

38. Olsson, E.G.A. The transformative potential of the food system concept. In Natural Resource Conflicts and Sustainable Development; Olsson, E.G.A., Gooch, P., Eds.; Routledge: New York, NY, USA, 2019; pp. 199-216, ISBN 9781138576896.

39. Olsson, E.G.A.; Kerselaers, E.; Søderkvist Kristensen, L.; Primdahl, J.; Rogge, E.; Wästfelt, A. Peri-urban food production and its relation to urban resilience. Sustainability 2016, 8, 1340. [CrossRef]

40. Miljöförvaltningen [Department of Environment Management]. Hållbar mat $i$ Göteborg: Nuläge, omvärldsbevakning och förslag inför fortsatt arbete [Sustainable food in Gothenburg: Current situation, external monitoring and proposals for continued work]; Gothen-burg: Gothenburg, Sweden, 2019.

41. Fermskog, K.; Dymitrow, M.; Ingelhag, K. From skipped free school lunches to poverty-induced food deserts: Some thoughts on Gothenburg's local food strategy-And how to make it happen. In Proceedings of the 3rd Mistra Urban Futures Annual International Conference: “Comparative Co-Production", Cape Town, South Africa, 5-7 November 2018.

42. Ingelhag, K.; Dymitrow, M.; Fermskog, K. Local food strategies for the future: Experiences from Gothenburg. In Proceedings of the Måltid Sverige: “Livsmedelsforum 2018” Conference, Gothenburg, Sweden, 11 October 2018. 
43. Eliasson, S.; Dymitrow, M.; Ingelhag, K.; Carlsson, M. Nutrition, health and climate: What have we learned so far? In Proceedings of the Conference on Food Science and Nutrition: "Forum for Food Science and Nutrition for a Better Tomorrow", Rome, Italy, 25-26 February 2019.

44. Dymitrow, M.; Ingelhag, K. (Eds.) Cities, Carrots and Camels: The Untold Stories from Running a Sustainability Project; Chalmers University of Technology (Mistra Urban Futures): Gothenburg, Sweden, 2019.

45. Fermskog, K.; Dymitrow, M. Gothenburg's applied food strategy: Meaningful—But how useful? In Proceedings of the Development Research Conference 2018: Rethinking Development, Gothenburg, Sweden, 22-23 August 2018.

46. Berners-Lee, M.; Harrison, G.; Parkin, M.; Hoolahan, C.; West, J.M.; Bows, A.; Wood, R. Sustainable Food in Manchester: Final Report. 2013. Available online: http://sfclancaster.org/wp-content/uploads/2013/10/ ManchesterSustainableFood131121Final.pdf (accessed on 10 May 2019).

47. Sheffield City Council. The Sheffield Food Strategy 2014-2017. 2014. Available online: http://democracy. sheffield.gov.uk/documents/s13929/FoodStrategy3.pdf (accessed on 10 May 2019).

48. Moragues-Faus, A.; Sonnino, R. Re-assembling sustainable food cities: An exploration of translocal governance and its multiple agencies. Urban Stud. 2018, 56, 778-794. [CrossRef]

49. Ogutu-Ohwayo, R. The decline of the native fishes of lakes Victoria and Kyoga (East Africa) and the impact of introduced species, especially the Nile perch, Lates niloticus, and the Nile tilapia, Oreochromis niloticus. Environ. Biol. Fishes 1990, 27, 81-96. [CrossRef]

50. Ntiba, M.J.; Kudoja, W.M.; Mukasa, C.T. Management issues in the Lake Victoria watershed. Lakes Reserv. Res. Manag. 2001, 6, 211-216. [CrossRef]

51. Onyango, G.M.; Obera, B. Tracing Kisumu's path in the co-production of knowledge for urban development. In Co-Producing Knowledge for Sustainable Cities: Joining Forces for Change; Polk, M., Ed.; Routledge: New York, NY, USA, 2015; pp. 70-97. ISBN 139780801885150.

52. Opiyo, P.; Ogindo, H.; Otiende, F.; Fuseini, I. Characteristics of the Urban Food System in Kisumu, Kenya; Consuming Urban Poverty Project, Working Paper No. 5; African Centre for Cities, University of Cape Town: Cape Town, South Africa, 2018.

53. Opiyo, P.; Obange, N.; Ogindo, H.; Wagah, G. The Characteristics, Extent and Drivers of Urban Food Poverty in Kisumu, Kenya; Consuming Urban Poverty Project Working Paper No. 4; African Centre for Cities, University of Cape Town: Cape Town, South Africa, 2018.

54. Battersby, J.; Haysom, G. Linking urban food security, urban food systems, poverty, and urbanisation. In Urban Food Systems Governance and Poverty in African Cities; Battersby, J., Watson, V., Eds.; Routledge: Oxon, UK, 2019; pp. 56-67. ISBN 9781138726758.

55. Opiyo, P.; Agong, S. The Importance of the Informal Food Sector in the Kisumu Food System; Consuming Urban Poverty Policy Brief; Policy Brief \#2; African Centre for Cities, University of Cape Town: Cape Town, South Africa, 2018.

56. Battersby, J.; Haysom, G.; Tawodzera, G.; McLagan, M.; Crush, J. Food System and Food Security Study for the City of Cape Town. 2014. Available online: http://www.afsun.org/wp-content/uploads/2016/08/FinalFood-System-Study-Report_Corrected-_WITH-COUNCIL-REPORT.pdf (accessed on 2 May 2019).

57. Battersby-Lennard, J.; Haysom, G. Philippi Horticultural Area-A City Asset or Potential Development Node? AFSUN: Cape Town, South Africa; Rooftops Canada Abri International: Toronto, ON, Canada, 2012.

58. Indigo; UMVOTO; SetPlan; Hoffman, W. Building the City of Cape Town's Resilience and Adding to Regional Competitiveness. In Philippi Horticultural Area: Socio-Economic Agricultural Plan; Western Cape Provincial Government: Elsenburg, South Africa, 2018.

59. Battersby, J. The State of Urban Food Insecurity in Cape Town. In Urban Food Security Series; No. 11; Queen's University: Kingston, ON, Canada; AFSUN: Cape Town, South Africa, 2011; ISBN 978-1-920409-71-5.

60. Crush, J.; Caesar, M.; Haysom, G. The State of Household Food Security in Cape Town, South Africa; Hungry Cities Partnership, Hungry Cities Report \#12; African Centre for Cities, UCT: Cape Town, South Africa; Balsillie School of International Affairs: Waterloo, ON, Canada, 2018; ISBN 978-1-920597-37-5.

61. Cafiero, C.; Viviani, S.; Nord, M. Food security measurement in a global context: The food insecurity experience scale. Measurement 2018, 116, 146-152. [CrossRef]

62. Haysom, G.; Tawodzera, G. Measurement drives diagnosis and response: Gaps in transferring food security assessment to the urban scale. Food Policy 2019, 74, 117-125. [CrossRef] 
63. Birkeland, J. Positive Development: From Vicious Circles to Virtuous Cycles through Built Environment Design; Earthscan: London, UK, 2008; ISBN 9781844075782.

64. Birkeland, J. Challenging policy barriers in sustainable development. Bull. Geogr. Soc. Econ. 2018, 40, 41-56.

65. Altieri, M.; Nicholls, C. Agrocecology and the Search for a Truly Sustainable Agriculture; United Nations Environment Programme Environmental Training Network for Latin America and the Caribbean: Cancun, Mexico, 2005.

66. Kate, T. From Industrial Agriculture to Agro Ecological Farming: A South African Perspective; Working Paper Series No. 10 ECSECC Working Paper Series; ECSECC: East London, South Africa, 2009.

67. Magdoff, F. Ecological agriculture: Principles, practices, and constraints. Renew. Agric. Food Syst. 2007, 22, 109-117. [CrossRef]

68. Altieri, M.A. Agroecology: The Science of Sustainable Agriculture, 2nd ed.; Westview Press: Boulder, CO, USA, 1995; ISBN 185339295.

69. Gliessman, S. Defining agroecology. Agroecol. Sust. Food 2018, 42, 599-600. [CrossRef]

70. Fukuoka, M. The One-Straw Revolution; Other India Press: Goa, India, 2007; ISBN 81-85569-31-2.

71. Bortoft, H. The Wholeness of Nature: Goethe's Way toward a Science of Conscious Participation in Nature; Lindisfarne Books: Aurora, CO, USA, 1996; ISBN 0-940262-79-7.

72. Mollison, B. Concepts and Themes in Design in Permaculture: A Designers Manual; Tagari Publications: Tyalgum, Australia, 1998; ISBN 0938228007.

73. Lal, R. Encyclopaedia of Soil Science, 2nd ed.; CRC Press: Columbus, OH, USA, 2005; ISBN 9780429110757.

74. Pearce, F. The Landgrabbers: The New Fight over Who Owns the Earth; Transworld Publishers: London, UK, 2012; ISBN 9781905811731.

75. World Business Council for Sustainable Development (WBCSD). Agricultural Ecosystems: Facts and Trends; World Business Council for Sustainable Development: Geneva, Switzerland, 2009.

76. Friedmann, H. From Colonialism to Green Capitalism: Social movements and the emergence of food regimes. In New Directions in the Sociology of Global Development; Buttel, F., McMichael, P., Eds.; Elsevier Press: Oxford, UK, 2005; pp. 227-264. ISBN 978-0-76231-250-4.

77. Patel, R. Stuffed and Starved; Melville House: New York, NY, USA, 2007; ISBN 978-1-554-68946-0.

78. Bennet, R. Farm animal welfare and food policy. Food Policy 1997, 22, 281-288. [CrossRef]

79. Webster, A. Farm Animal Welfare: The Five Freedoms and the Free Market. Vet. J. 2001, 161, $229-237$. [CrossRef]

80. Soja, E. Postmetropolis: Critical Studies of City Regions; Blackwell: Oxford, UK, 2000; ISBN 978-1-577-18001-2.

81. Feenstra, G. Creating space for sustainable food systems: Lessons from the field. Agric. Hum. Values 2002, 19, 99-106. [CrossRef]

82. Goodman, D.; Goodman, M. Alternative food networks. In International Encyclopedia of Human Geography; Kitchen, R., Thrift, N., Eds.; Elsevier: Oxford, UK, 2009; Volume 8, ISBN 978-0-08-044919-7.

83. McClintock, N. Why farm the city? Theorizing urban agriculture through a lens of metabolic rift. Camb. J. Reg. Econ. Soc. 2010, 3, 191-207. [CrossRef]

84. Natural Resources Defence Council (NRDC). Food Miles: Health Facts; Natural Resources Defence Council: California, CA, USA, 2007.

85. Collins, A.; Fairchild, R. Sustainable Food Consumption at a Sub-national Level: An Ecological Footprint, Nutritional and Economic Analysis. J. Environ. Policy Plan. 2007, 9, 5-30. [CrossRef]

86. FoodChoices Food and Our Ecological Footprint; Resource Sheet \#56; Curriculum Resource: Sydney, Australia, 2009; Available online: http://www.foodchoices.com.au/samples/resource\%20sheet\%2056.pdf (accessed on 4 March 2019).

87. Borron, S. Food Policy Councils: Practice and Possibility; Hunger-Free Community Report; Congressional Hunger Center: Washington, DC, USA, 2003.

88. MacRae, R. A Joined-Up Food Policy for Canada. J. Hunger. Environ. Nutr. 2011, 6, 424-457. [CrossRef]

89. Morgan, K.; Sonnino, R. The urban foodscape: World cities and the new food equation. Camb. J. Reg. Econ. Soc. 2010, 3, 209-224. [CrossRef]

90. Roberts, W. The Way to a city's heart is through its stomach: Putting food security on the urban planning menu. In Crackerbarrel Philosophy Series; Toronto Food Policy Council: Toronto, ON, Canada, 2001. 
91. Blay-Palmer, A.; Renting, H.; Dubbeling, M. Understanding the city region (CRFS) food system: Planning for a more food secure and resilient city-City-region food systems-A literature review. In CityFoodTools Project and Framework for City Region Food Systems (CRFS) Assessment; RUAF and FAO: Leusden, The Netherlands, 2015.

92. Ericksen, P. Conceptualizing food systems for global environmental change research. Glob. Environ. Chang. 2008, 18, 234-245. [CrossRef]

93. Blay-Palmer, A.; Santini, G.; Dubbeling, M.; Renting, H.; Taguchi, M.; Giordano, T. Validating the city region food system approach: Enacting inclusive, transformational city region food systems. Sustainability 2018, 10, 1680. [CrossRef]

94. Schipanski, M.E.; Macdonald, G.K.; Rosenzwig, S.; Chappell, M.J.; Bennett, E.M.; Bezner Kerr, R.; Blesh, J.; Crews, T.; Drinkwater, L.; Lundgren, J.G.; et al. Realizing resilient food systems. BioScience 2016, 6, 600-610. [CrossRef]

95. Ecker, O.; Breisinger, C. The Food Security System: A New Conceptual Framework; IFPRI Discussion Paper 01166; Development Strategy and Governance Division, IFPRI: Washington, DC, USA, 2012.

96. Sen, A. Poverty and Famines: An Essay on Entitlement and Deprivation; Clarendon Press: Oxford, UK, 1981; ISBN 9780198284635.

97. Rinaldi, C. Food and gastronomy for sustainable place development: A multidisciplinary analysis of different theoretical approaches. Sustainability 2017, 9, 1748. [CrossRef]

98. Ritchie, J.; Lewis, J. Qualitative Research Practice: A Guide for Social Science Researchers; Sage: London, UK, 2003; ISBN 0761971106.

99. Srivastava, A.; Thomson, S.B. Framework analysis: A qualitative methodology for applied policy research. J. Adm. Gov. 2009, 4, 72-79.

100. Ward, D.J.; Furber, C.; Tierney, S.; Swallow, V. Using framework analysis in nursing research: A worked example. J. Adv. Nurs. 2013, 69, 2423-2431. [CrossRef]

101. Dymitrow, M.; Brauer, R. Performing rurality. But who? Bull. Geogr. Soc. Econ. 2017, 38, 27-45. [CrossRef]

102. Dorado, S.; Giles, D.E., Jr.; Welch, T.C. Delegation of coordination and outcomes in cross-sector partnerships: The case of service learning partnerships. Nonprofit Volunt. Sect. Q. 2009, 38, 368-391. [CrossRef]

103. Rein, M.; Stott, L. Working together: Critical perspectives on six cross-sector partnerships in southern Africa. J. Bus. Ethics 2009, 90, 79-89. [CrossRef]

104. Powell, E.; Hamann, R.; Bitzer, V.; Baker, T. Bringing the elephant into the room? Enacting conflict in collective prosocial organizing. J. Bus. Vent. 2018, 33, 623-642. [CrossRef]

105. Drimie, S. Response in Summarising MISTRA Urban Food Systems Working Group Meeting. Available online: https://realisingjustcities-rjc.org/news/mistra-urban-futures-conference-2018-cape-town (accessed on 17 June 2019).

106. Rittel, H.W.; Webber, M.M. Dilemmas in a general theory of planning. Policy Sci. 1973, 4, 155-169. [CrossRef]

107. Lazarus, R. Super wicked problems and climate change: Restraining the present to liberate the future. Cornell Law Rev. 2008, 94, 1153-1233.

(C) 2019 by the authors. Licensee MDPI, Basel, Switzerland. This article is an open access article distributed under the terms and conditions of the Creative Commons Attribution (CC BY) license (http://creativecommons.org/licenses/by/4.0/). 